\title{
Experimental Investigating of Rotary Ultrasonic Grinding for Ceramic Edging
}

\author{
Zhiguo $\mathrm{Li}^{1}$, Zhen $\mathrm{Yao}^{1,{ }^{1}}$, Yongjun Zhang ${ }^{1}$, Gang Guo ${ }^{1}$, Caihong Chen ${ }^{1}$ and Hangjian Liu ${ }^{1}$ \\ ${ }^{1}$ School of Electro-mechanical Engineering, Guangdong University of Technology, No. 100, Waihuan Xi Road, Guangzhou \\ Higher Education Mega Center, Panyu District, Guangzhou, P.R China \\ ${ }^{*}$ Corresponding author
}

\begin{abstract}
In order to reduce the grinding force, cutting heat, grinding wheel abrasion and improve the qualities of the ceramic production, my paper describes the ceramic edge grinding machine spindle with ultrasonic vibration. The order of influencing factors (such as spindle speed, feed speed, grinding amount and ultrasound current) on three directions force and grinding force are sorted, and the reason is analyzed. The paper concludes that feed speed and grinding amount play a major role in the grinding force, while spindle speed and ultrasonic current intensity plays a secondary role.
\end{abstract}

Keyword-rotary ultrasonic machining; edging; three-direction force; grinding force; ceramic

\section{INTRODUCTION}

Ultrasonic machining has great advantages in grinding hard and brittle materials, such as low cutting force, low cutting heat, high surface quality of workpieces, easy chip handling and high tool durability ${ }^{[1][2][3]}$. With the development of materials science, the demand for processing brittle materials has been rapidly increasing in recent decades ${ }^{[4][5]}$. As a non-traditional machining method, rotary ultrasonic machining (RUM) is more and more used in the field of military, aerospace and high technology materials processing in recent years, such as composite materials, cemented carbide, ceramics and glass. However, the development of equipment of rotary ultrasonic machine in our country is lagging behind, and most of the research about ultrasonic processing technology still stays in the laboratory, has not appeared a market-oriented machine tools nowadays ${ }^{[6][7][8]}$.

Famous rotary ultrasonic machine such as DMG company's ULTRASONIC 10 with price of about RMB 4.5 million $^{[9]}$. It's difficult to find out the ordinary processing machine with a rotary ultrasonic especially in the traditional ceramic industry both in domestic and foreign. Based on the immature application of rotary ultrasonic processing equipment in ceramic machinery, the Institute of Manufacturing Technology of Guangdong University of Technology designed the ceramic edge grinding machine spindle with ultrasonic assisted vibration ${ }^{[10][11]}$. By adding a rotating ultrasonic spindle to the existing ceramic production line, the grinding force during the grinding process of the ceramic tile is reduced, the cutting heat is reduced, the abrasion loss of the grinding wheel and the numbers of tile collapse are reduced ${ }^{[12]}$.

\section{EXPERIMENTAL DETAIL}

\section{A. Experimental Setup and Cutting Force Measurement}

The system of RUM ceramic edging grinding consists of three parts including motion control system, ultrasonic vibration system and data acquisition system. The experimental setup was shown in Figure 1. Among them, the ultrasonic power supply is a circuit that converts low frequency mains $(50 \mathrm{~Hz})$ into high frequency $\mathrm{AC}$ signal $(20 \mathrm{KHz})$ that matches the ultrasonic transducer. The ultrasonic power supplies the ultrasonic transducer through a brush set inside the spindle. Receiving the signal, the transducer transforms electrical signals into high-frequency mechanical vibration, amplified by the booster and transmitted to the edge grinding wheel. Input motion control parameters into the PLC touch screen, we can control the spindle speed, grinding amount and feed rate by controlling the three-phase AC motor or the stepper motors. In order to get the best processing parameters, install the Kistler 9257B dynamometer under the fixture. Through amplify and convert the dynamometer signal, we can collect three-direction force data during processing. 


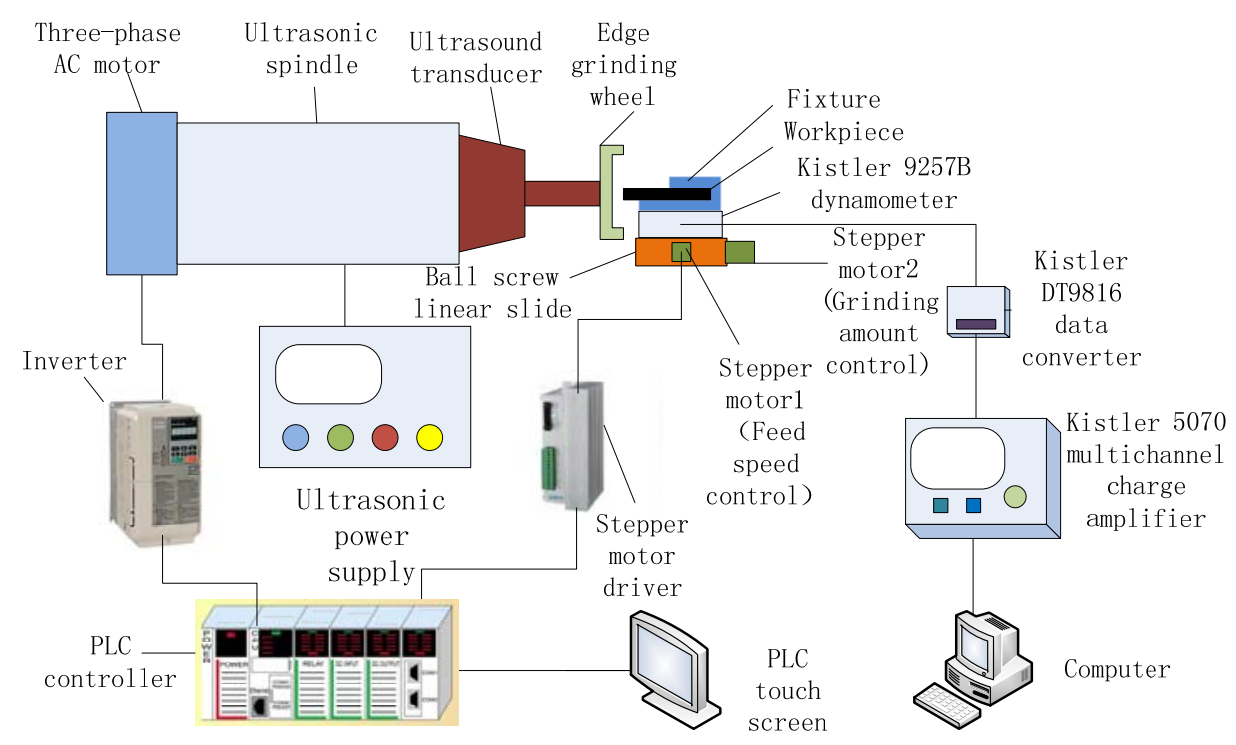

FIGURE I. SYSTEM OF RUM CERAMIC EDGING GRINDING

\section{B. Workpiece Material Properties}

The ceramic workpiece used in this experiment had the size of $300 \mathrm{~mm} \times 300 \mathrm{~mm} \times 7.8 \mathrm{~mm}$. Properties of ceramic workpiece material are listed in Table 1.

TABLE I. PROPERTIES OF CERAMIC WORKPIECE MATERIAL

\begin{tabular}{llll}
\hline & \multicolumn{1}{c}{$\begin{array}{c}\text { Water } \\
\text { absorption }\end{array}$} & $\begin{array}{c}\text { Destruction } \\
\text { strength }\end{array}$ & $\begin{array}{c}\text { Rupture } \\
\text { modulus }\end{array}$ \\
\hline $\begin{array}{l}\text { standard } \\
\text { requirement } \\
\text { test result }\end{array}$ & $6 \%<\mathrm{E} \leq 10 \%$ & $\geq 800 \mathrm{~N}$ & $\geq 18 \mathrm{MPa}$ \\
\hline
\end{tabular}

\section{Experimental Conditions}

Several assumptions about RUM ceramic edging grinding include the following:

1. The material is removed by brittle fracture.

2. During the experiment, edging wheel maintain the same sharpness.

3. The ultrasonic vibration during the machining process is stable (frequency and amplitude remain unchanged) and current intensity is linear with ultrasonic amplitude.

\section{ORTHOGONAL EXPERIMENT}

In the tile processing, the size and direction of the force is one of the important factors that directly affect the quality of the workpiece surface and edge grinding wheel wear. In orthogonal experiments, summarize the effects of four machining variables that spindle speed, feed speed, grinding amount and ultrasonic current intensity on the grinding forces during the tile edging. The grinding force is calculated from three directions force using Equation 1.

$$
F_{\text {Grinding }}=\sqrt{F_{\text {Feed }}^{2}+F_{\text {Axial }}^{2}+F_{\text {Radial }}^{2}}
$$

As a total of four factors in this experiment, we use $\mathrm{L}_{9}\left(3^{4}\right)$ orthogonal table design the test. The factors and levels of orthogonal experimental design are shown in Table 2. The experimental parameters of each group are shown in Table 3.

TABLE II. FACTORS AND LEVELS OF ORTHOGONAL EXPERIMENTAL DESIGN

\begin{tabular}{lllll}
\hline & \multicolumn{3}{c}{ Factor } \\
\hline Level & $\begin{array}{l}\text { Spindle } \\
\text { speed } \\
(\mathrm{rpm})\end{array}$ & $\begin{array}{c}\text { Feed speed } \\
(\mathrm{mm} / \mathrm{s})\end{array}$ & $\begin{array}{l}\text { Grinding } \\
\text { amount } \\
(\mathrm{mm})\end{array}$ & $\begin{array}{l}\text { Ultrasound } \\
\text { current }(\mathrm{A})\end{array}$ \\
1 & 900 & 10 & 0.1 & 0.4 \\
2 & 1500 & 20 & 0.2 & 1.0 \\
3 & 2100 & 30 & 0.3 & 1.6 \\
\hline
\end{tabular}

TABLE III. GRINDING EXPERIMENT ORTHOGONAL TEST DESIGN

\begin{tabular}{lllll}
\hline Experiment & \multicolumn{4}{c}{ Factor } \\
& $\begin{array}{c}\text { Spindle } \\
\text { speed } \\
\mathbf{( r p m )}\end{array}$ & $\begin{array}{c}\text { Feed } \\
\text { speed } \\
(\mathbf{m m} / \mathbf{s})\end{array}$ & $\begin{array}{c}\text { Grinding } \\
\text { amount } \\
\mathbf{( m m )}\end{array}$ & $\begin{array}{c}\text { Ultrasound } \\
\text { current }\end{array}$ \\
1 & 900 & 10 & 0.1 & 0.4 \\
2 & 900 & 20 & 0.2 & 1.0 \\
3 & 900 & 30 & 0.3 & 1.6 \\
4 & 1500 & 10 & 0.2 & 1.6 \\
5 & 1500 & 20 & 0.3 & 0.4 \\
6 & 1500 & 30 & 0.1 & 1.0 \\
7 & 2100 & 10 & 0.3 & 1.0 \\
8 & 2100 & 20 & 0.1 & 1.6 \\
9 & 2100 & 30 & 0.2 & 0.4 \\
\hline
\end{tabular}

After 4 repeated experiments, exported the force data into Excel during processing. First of all, take the data as absolute value and then averaged the result to obtain the size of three directions force. The average result of each direction and calculated grinding force value are shown in Table 4. 
TABLE IV. ORTHOGONAL TEST RESULTS

\begin{tabular}{|c|c|c|c|c|c|c|c|c|}
\hline & \multicolumn{4}{|c|}{ Factor } & \multicolumn{4}{|c|}{ Result } \\
\hline Experiment & $\begin{array}{l}\text { Spindle } \\
\text { speed } \\
\text { (rpm) }\end{array}$ & $\begin{array}{c}\text { Feed } \\
\text { speed } \\
(\mathrm{mm} / \mathrm{s})\end{array}$ & $\begin{array}{c}\text { Grinding } \\
\text { amount } \\
\text { (mm) }\end{array}$ & $\begin{array}{l}\text { Ultrasound } \\
\text { current } \\
\text { (A) }\end{array}$ & $\begin{array}{c}\text { Feed } \\
\text { direction } \\
\text { force }(\mathrm{N})\end{array}$ & $\begin{array}{c}\text { Axial } \\
\text { force } \\
(\mathrm{N})\end{array}$ & $\begin{array}{l}\text { Radial } \\
\text { force } \\
\text { (N) }\end{array}$ & $\begin{array}{l}\text { Grinding } \\
\text { force }(\mathrm{N})\end{array}$ \\
\hline 1 & 1 & 1 & 1 & 1 & 12.49 & 34.46 & 12.63 & 43.17 \\
\hline 2 & 1 & 2 & 2 & 2 & 15.73 & 42.48 & 12.87 & 51.00 \\
\hline 3 & 1 & 3 & 3 & 3 & 28.72 & 88.21 & 18.10 & 98.28 \\
\hline 4 & 2 & 1 & 2 & 3 & 16.43 & 38.53 & 14.10 & 49.39 \\
\hline 5 & 2 & 2 & 3 & 1 & 22.58 & 58.95 & 14.93 & 70.04 \\
\hline 6 & 2 & 3 & 1 & 2 & 19.06 & 58.60 & 12.65 & 66.53 \\
\hline 7 & 3 & 1 & 3 & 2 & 19.32 & 33.73 & 19.18 & 49.17 \\
\hline 8 & 3 & 2 & 1 & 3 & 17.19 & 33.95 & 18.02 & 47.47 \\
\hline 9 & 3 & 3 & 2 & 1 & 23.85 & 48.63 & 18.91 & 63.27 \\
\hline
\end{tabular}

According to the result in table 4 , we can calculate the range analysis of three directions force and grinding force as shown in table 5 to 8 . The greater of range's number, the greater effect of this factor on the experimental index.

TABLE V. RANGE ANALYSIS OF FEED DIRECTION FORCE

\begin{tabular}{ccccc}
\hline & $\begin{array}{c}\text { Spindle } \\
\text { speed } \\
\text { (rpm) }\end{array}$ & $\begin{array}{c}\text { Feed } \\
\text { speed } \\
(\mathbf{m m} / \mathbf{s})\end{array}$ & $\begin{array}{c}\text { Grinding } \\
\text { amount } \\
\mathbf{( m m )}\end{array}$ & $\begin{array}{c}\text { Ultrasound } \\
\text { current } \\
(\mathbf{A})\end{array}$ \\
\hline Mean 1 & 18.980 & 16.080 & 16.247 & 19.640 \\
Mean 2 & 19.357 & 18.500 & 18.670 & 18.037 \\
Mean 3 & 20.120 & 23.877 & 23.540 & 20.780 \\
Range & 1.140 & 7.797 & 7.293 & 2.743 \\
\hline
\end{tabular}

TABLE VI. RANGE ANALYSIS OF AXIAL FORCE

\begin{tabular}{ccccc}
\hline & $\begin{array}{c}\text { Spindle } \\
\text { speed } \\
\text { (rpm) }\end{array}$ & $\begin{array}{c}\text { Feed } \\
\text { speed } \\
(\mathbf{m m} / \mathbf{s})\end{array}$ & $\begin{array}{c}\text { Grinding } \\
\text { amount } \\
(\mathbf{m m})\end{array}$ & $\begin{array}{c}\text { Ultrasound } \\
\text { current } \\
(\mathbf{A})\end{array}$ \\
\hline Mean 1 & 55.050 & 35.573 & 42.337 & 47.347 \\
Mean 2 & 52.027 & 45.127 & 43.213 & 44.937 \\
Mean 3 & 38.770 & 65.147 & 60.297 & 53.563 \\
Range & 16.280 & 29.574 & 17.960 & 8.626 \\
\hline
\end{tabular}

TABLE VII. RANGE ANALYSIS OF RADIAL FORCE

\begin{tabular}{llllc}
\hline & $\begin{array}{c}\text { Spindle } \\
\text { speed } \\
\text { (rpm) }\end{array}$ & $\begin{array}{c}\text { Feed } \\
\text { speed } \\
\mathbf{( m m / s )}\end{array}$ & $\begin{array}{c}\text { Grinding } \\
\text { amount } \\
\mathbf{( m m )}\end{array}$ & $\begin{array}{c}\text { Ultrasound } \\
\text { current } \\
\mathbf{( A )}\end{array}$ \\
\hline Mean 1 & 14.533 & 15.303 & 14.433 & 15.490 \\
Mean 2 & 13.893 & 15.273 & 15.293 & 14.900 \\
Mean 3 & 18.703 & 16.553 & 17.403 & 16.740 \\
Range & 4.810 & 1.280 & 2.970 & 1.840 \\
\hline
\end{tabular}

TABLE VIII. RANGE ANALYSIS OF GRINDING FORCE

\begin{tabular}{lcccc}
\hline & $\begin{array}{c}\text { Spindle } \\
\text { speed } \\
\text { (rpm) }\end{array}$ & $\begin{array}{c}\text { Feed } \\
\text { speed } \\
(\mathbf{m m} / \mathbf{s})\end{array}$ & $\begin{array}{c}\text { Grinding } \\
\text { amount } \\
(\mathbf{m m})\end{array}$ & $\begin{array}{c}\text { Ultrasound } \\
\text { current } \\
(\mathbf{A})\end{array}$ \\
\hline $\begin{array}{l}\text { Mean } \\
1\end{array}$ & 64.150 & 47.243 & 52.390 & 58.827 \\
$\begin{array}{l}\text { Mean } \\
2\end{array}$ & 61.987 & 56.170 & 54.553 & 55.567 \\
$\begin{array}{l}\text { Mean } \\
3\end{array}$ & 53.303 & 76.027 & 72.497 & 65.047 \\
Range & 10.847 & 28.784 & 20.107 & 9.480 \\
\hline
\end{tabular}

Therefore, it can be concluded from table 5 that the influencing factors on the feed direction force in the order of feed speed, grinding amount, ultrasonic current and spindle speed. Due to the direction of feed speed and feed direction force in the same line, it is obvious that the results in line with the actual processing conditions.

It also can be concluded from table 6 that the influence of axial force in the order of feed speed, grinding capacity, spindle speed and ultrasonic current. It can be seen from the above sequence that among the factors that affect the feed direction force and the axial force, the feed speed and the grinding amount play a major role, while the spindle speed and the ultrasonic current intensity have a secondary influence.

The order of influence on the radial force is the spindle speed, grinding amount, ultrasonic current and feed rate. When the spindle rotates, the force generated by the edging wheel removing the edge material of the ceramic tile is collinear with the radial force, so the spindle speed has a major influence on the radial force.

Calculate the grinding force through the formula 1, the order of the influence of the grinding force is the feed speed, grinding amount, spindle speed and ultrasonic current. Obvious, the factors affect the size of grinding force are the same as the order of axial force. Because the two sizes of feed direction force and radial force have the same magnitude and the magnitude of axial force is 2 to 3 times the feed direction force. Therefore, the size of the axial force plays a major role on the size of the grinding force. Based on the result, we should ensure strength of axial direction when we design the spindle with ultrasonic.

\section{CONCLUSIONS}

The explore about rotary ultrasonic machining of composites or cemented carbide used a smaller feed speed and grinding amount to ensure the effectiveness of ultrasonic vibration in the past. This study innovatively applied rotary ultrasonic processing in the occasion of large feed speed and grinding amount, using in the ceramic edging production line. Some main conclusions were drawn as follows:

1. The size of the axial force has the greatest impact of grinding force in the three-direction force. In the design of the mechanism, it is necessary to ensure the axial rigidity and reduce the axial force with the help of ultrasonic vibration.

2. Feed speed and grinding amount play a major role in the grinding force, while spindle speed and ultrasonic current intensity plays a secondary role.

\section{ACKNOWLEDGEMENTS}

The work was supported by Science and Technology 
Planning Project of Guangdong Province, China. (Item Number: 2016A010102017).

\section{REFERENCE}

[1] Abbas N M, Solomon D G, Bahari M F. A review on current research trends in electrical discharge machining (EDM) [J]. International Journal of Machine Tools \& Manufacture, 2007, 47(7-8):1214-1228.

[2] Azmir M A, Ahsan A K. A study of abrasive water jet machining process on glass/epoxy composite laminate[J]. Journal of Materials Processing Technology, 2009, 209(20):6168-6173.

[3] Nik M G, Movahhedy M R, Akbari J. Ultrasonic-Assisted Grinding of Ti6Al4 V Alloy[J]. Procedia Cirp, 2012, 1(1):353-358.

[4] Ning F, Cong W, Wang H, et al. Surface grinding of CFRP composites with rotary ultrasonic machining: a mechanistic model on cutting force in the feed direction[J]. International Journal of Advanced Manufacturing Technology, 2017(5):1-13.

[5] Liu D F, Cong W L, Pei Z J, et al. A cutting force model for rotary ultrasonic machining of brittle materials[J]. International Journal of Machine Tools \& Manufacture, 2012, 52(1):77-84.

[6] Jian-chun WANG. Research Status and Prospect of Ultrasonic Machining Technology [J]. Mechanical Engineers, 2012(4): 6-11.

[7] Feng-guo CAO, Qin-jian ZHANG. Research Status and Development Trend of Ultrasonic Machining Technology [J]. Electromachining \& Mould, 2005(s1):25-31.

[8] De-yuan ZHANG, Wen-long XIN, Xing-gang JIANG. Ultrasonic processing technology research trends [J]. Electromachining \& Mould, 2016(s1):11-13.

[9] Shi-liang WEI, Hong Zhao, Kai Xie. Research on Cutting Force of Rotating Ultrasonic Grinding of Engineering Ceramics in Fragile Domain [J]. Journal of Harbin Engineering University, 2014(8):976-981.

[10] Yue Tang. Design and Experiment of Ultrasonic Vibration System for Tile Edger [D]. Guangdong University of Technology, 2016.

[11] Jin-kun ZHANG. Research and Design of Ceramic Abrasive Ultrasonic Machining Power Supply [D]. Guangdong University of Technology, 2015.

[12] Jiao Zhang. Experimental Research on Ceramic Ultrasonic Auxiliary Grinding [D]. Guangdong University of Technology, 2016. 